\title{
Miranda
}

Revue pluridisciplinaire du monde anglophone /

Multidisciplinary peer-reviewed journal on the English-

speaking world

15 | 2017

Lolita at 60 / Staging American Bodies

\section{Twelfth Night by William Shakespeare and Anatomy of a Suicide by Alice Birch}

Performance Review

William C. Boles

\section{(2) OpenEdition}

\section{Journals}

\section{Electronic version}

URL: http://journals.openedition.org/miranda/11025

DOI: 10.4000/miranda. 11025

ISSN: 2108-6559

\section{Publisher}

Université Toulouse - Jean Jaurès

\section{Electronic reference}

William C. Boles, "Twelfth Night by William Shakespeare and Anatomy of a Suicide by Alice Birch", Miranda [Online], 15 | 2017, Online since 06 October 2017, connection on 16 February 2021. URL: http://journals.openedition.org/miranda/11025 ; DOI: https://doi.org/10.4000/miranda. 11025

This text was automatically generated on 16 February 2021

\section{(c) (i) $(9)$}

Miranda is licensed under a Creative Commons Attribution-NonCommercial-NoDerivatives 4.0 International License. 


\section{Twelfth Night by William}

\section{Shakespeare and Anatomy of a Suicide by Alice Birch}

Performance Review

William C. Boles

\section{Factual information about the shows}

Play : Twelfth Night by William Shakespeare

Place : Globe Theatre (London)

Running time : May $18^{\text {th }}, 2017$-August $5^{\text {th }}, 2017$

Director : Emma Rice

5 Designer : Lez Brotherston

6 Composer : Ian Ross

Choreographer : Etta Murfitt

Lighting Designer : Malcolm Rippeth

9 Sound Designer : Simon Baker

10 Fight Directors : Rachel Bown-Williams \& Ruth Cooper Brown of RC-Annie Ltd.

11 Cast: Marc Antolin, Carly Bawden, Nandi Bhebhe, Tony Jayawardena, Joshua Lacey, Pieter Lawman, Le Gateau Chocolat, Annette McLaughlin, Kandaka Moore, Katy Owen, John Pfumojena, Theo St. Claire, Anita-Joy Uwajeh 


\section{Figure 1}

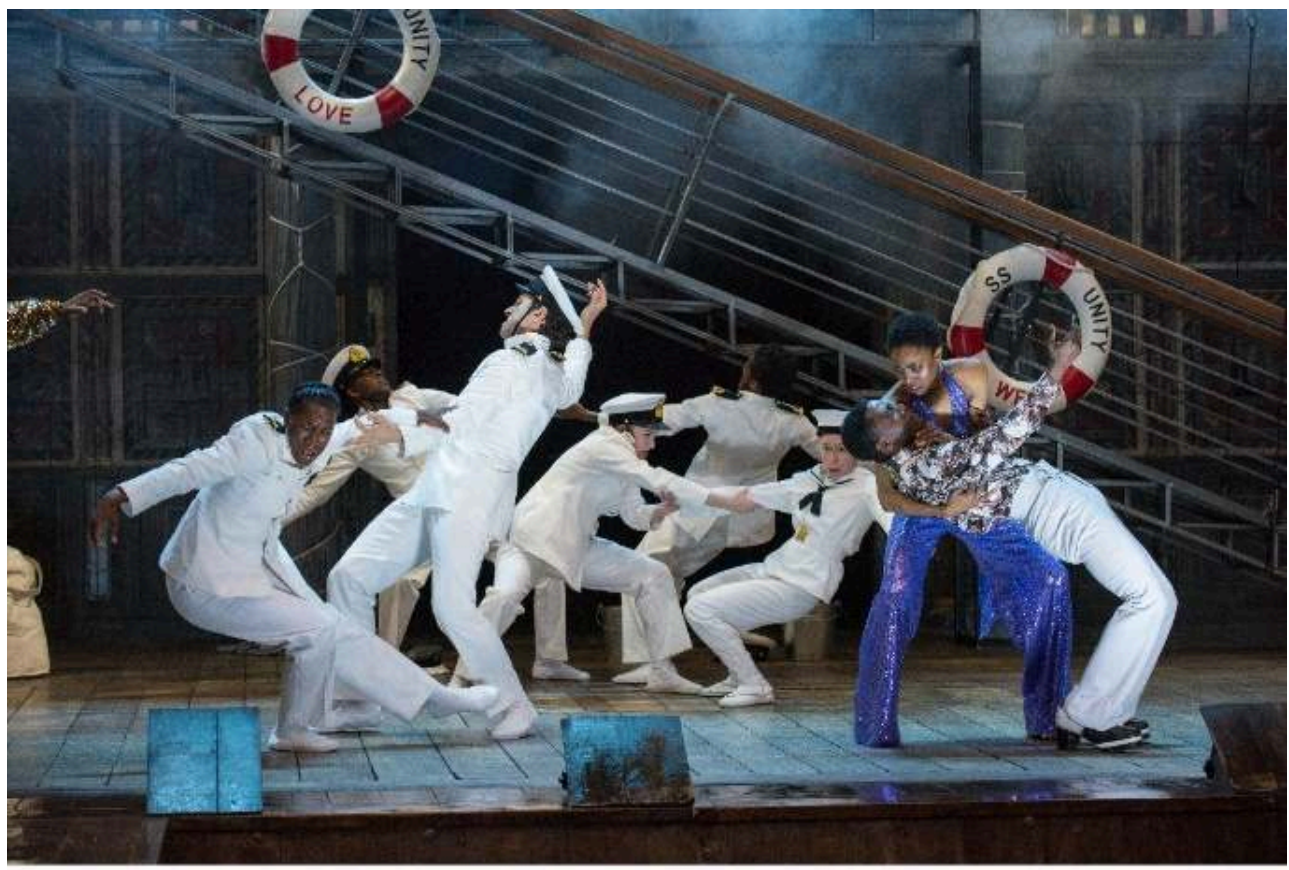

Full Company (Sailors), John Pfumojena (Sebastan) and An ta-Joy Uwajeh (Nola) in Emma Rice's Twellhh Night, playing 18 May Theatre

ingo Glend nning

For more information please contact Shakespeare's Globe press ofitice on $+44\{0\rangle 2079021492$

John Pfumojena (Sebastian) and Anita-Joy Uwajeh (Viola)

Credits: Hugo Glendinning 


\section{Figure 2}

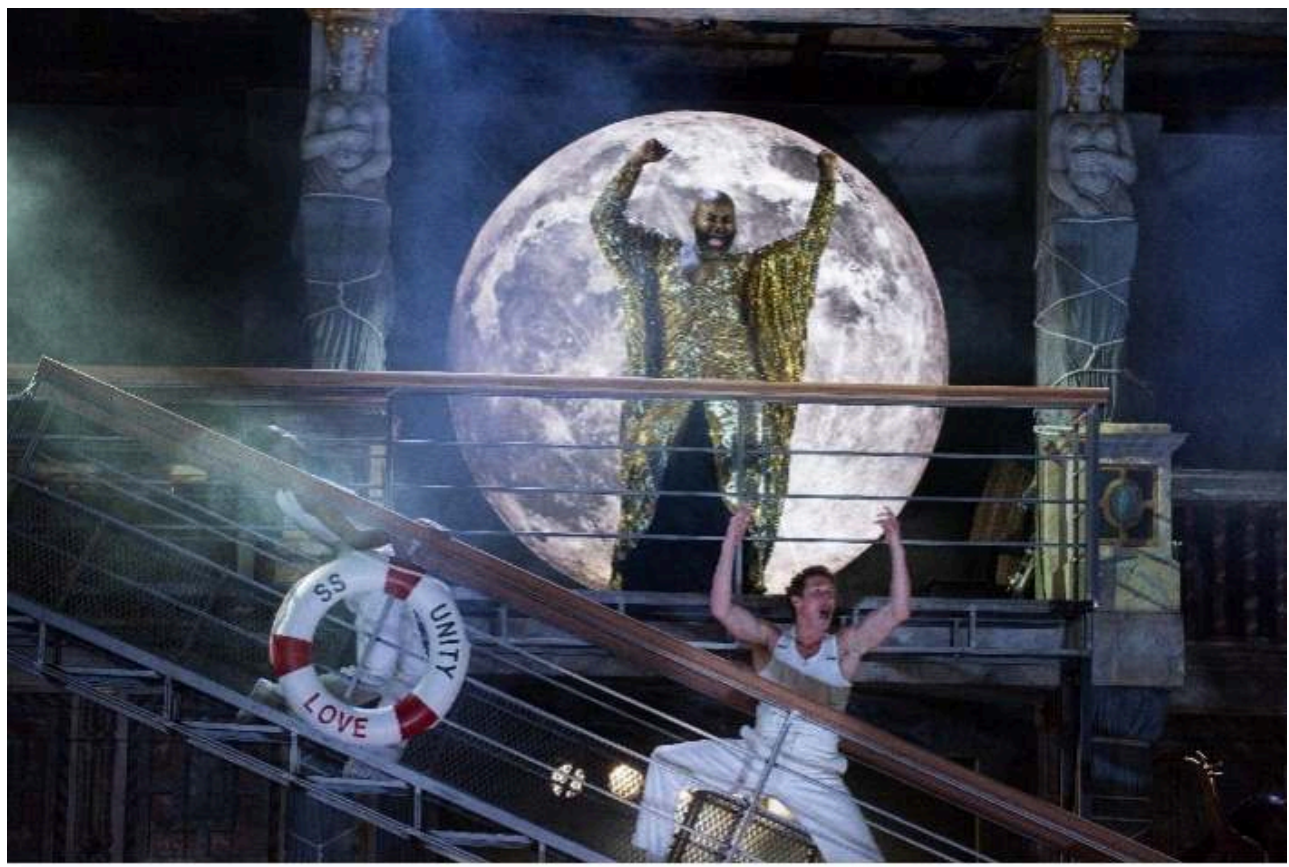

Le Gateau Chocclat as Feste and Joshua Lacey as Sallor in Emma Rice's Twoith Night, playing 18 May - 5 August in the Globe Theatre. Please crecit photographer Hugo Glend nning

For more information please contact Shakespeare's Globe press office on $+44(0) 2071492$

La Gateau Chocolat (Feste), Joshua Lacey (Sailor)

Credits: Hugo Glendinnig 


\section{Figure 3}

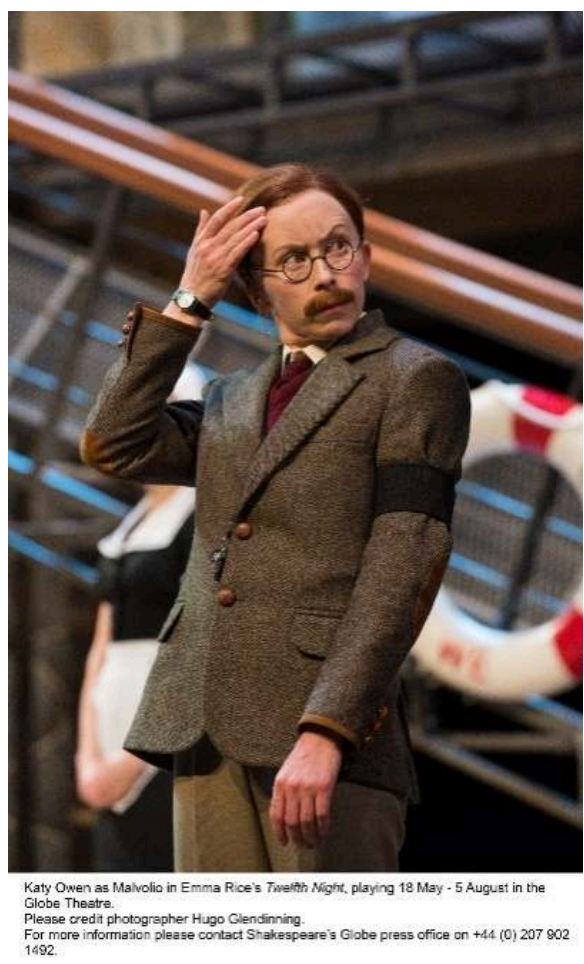

Katy Owen (Malvolio)

Credits: Hugo Glendinning 


\section{Figure 4}

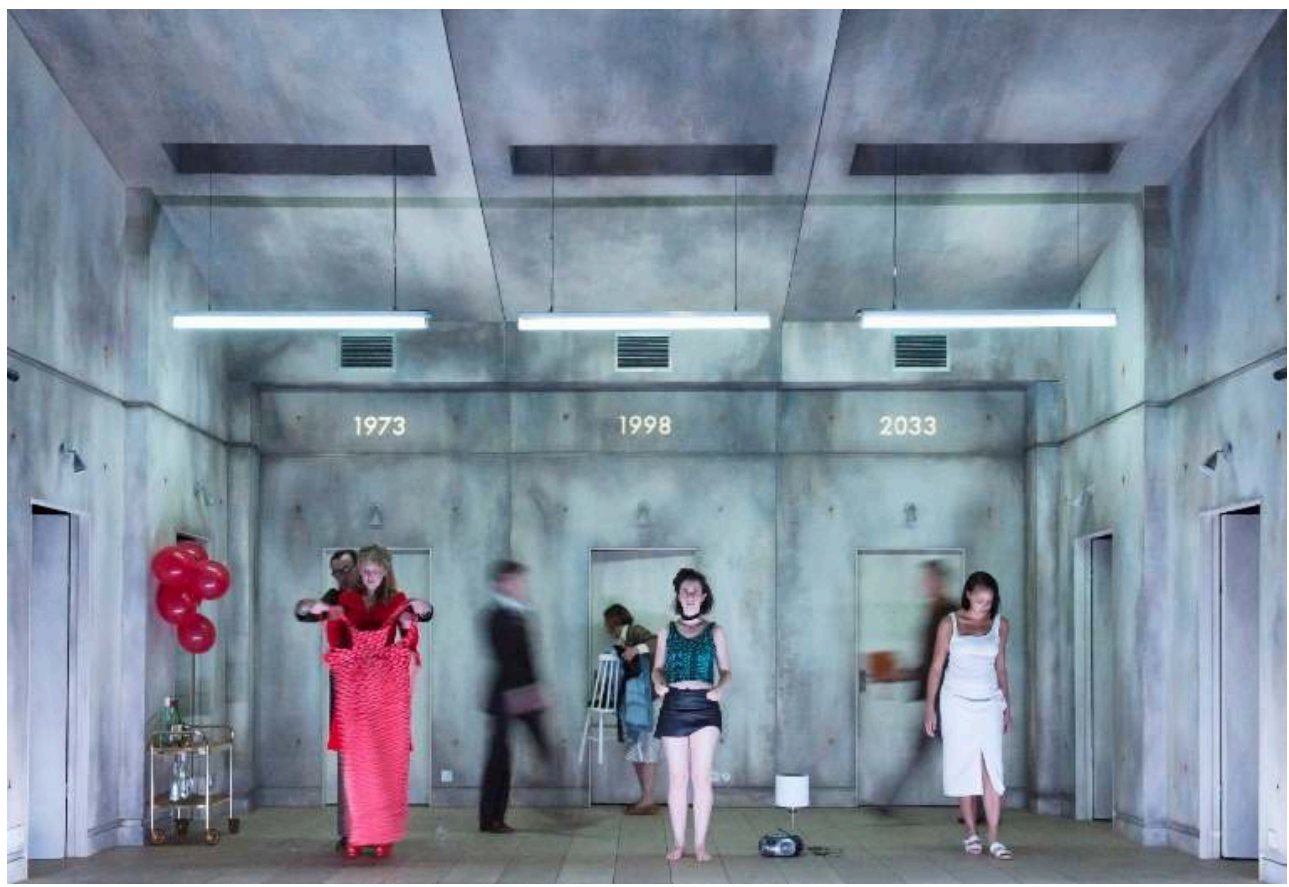

Hattie Morahan (Carol), Kate O'Flynn (Anna), and Adelle Leonce (Bonnie) Credits : Stephen Cummiskey

\section{Figure 5}

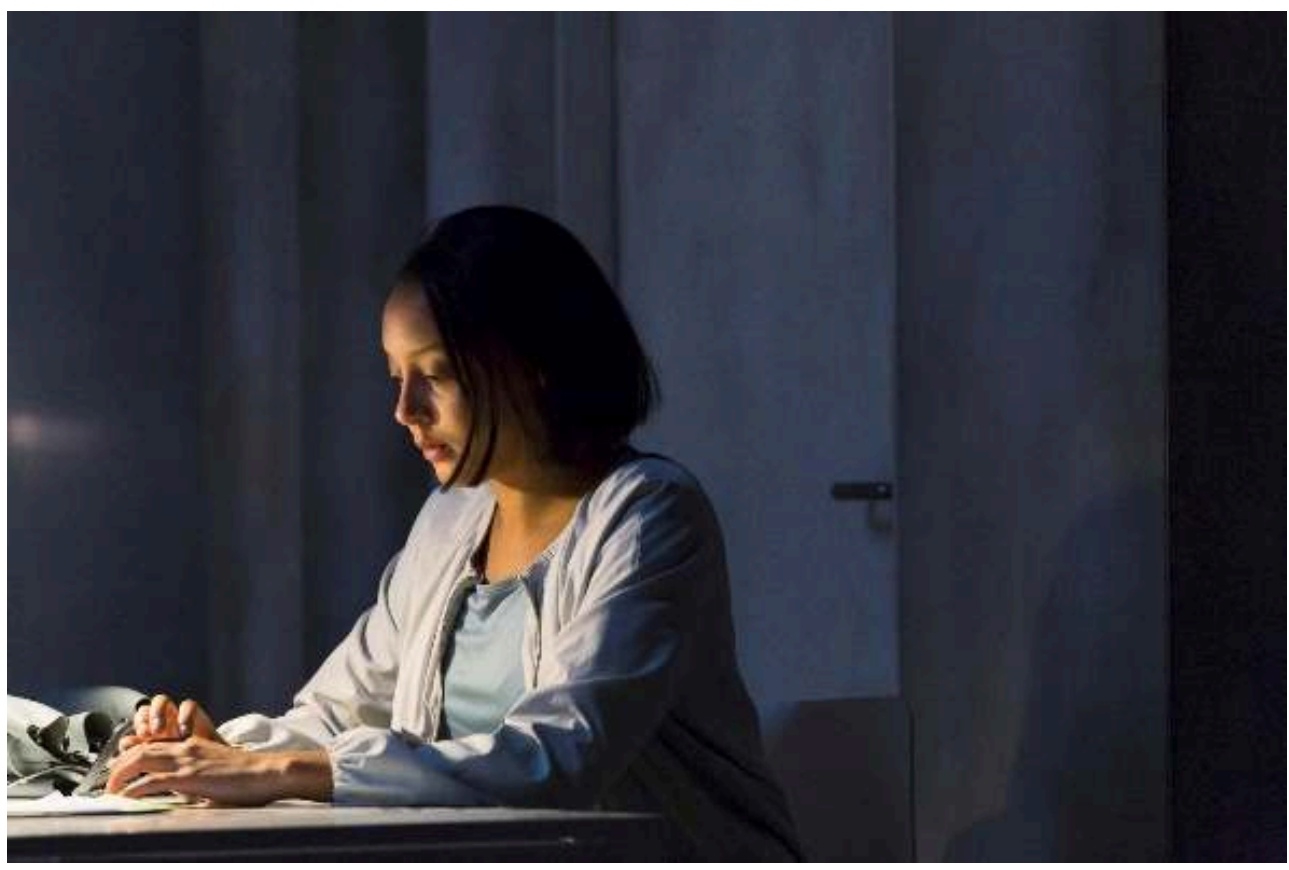

Adelle Leonce (Bonnie)

Credits : Stephen Cummiskey 


\section{Figure 6}

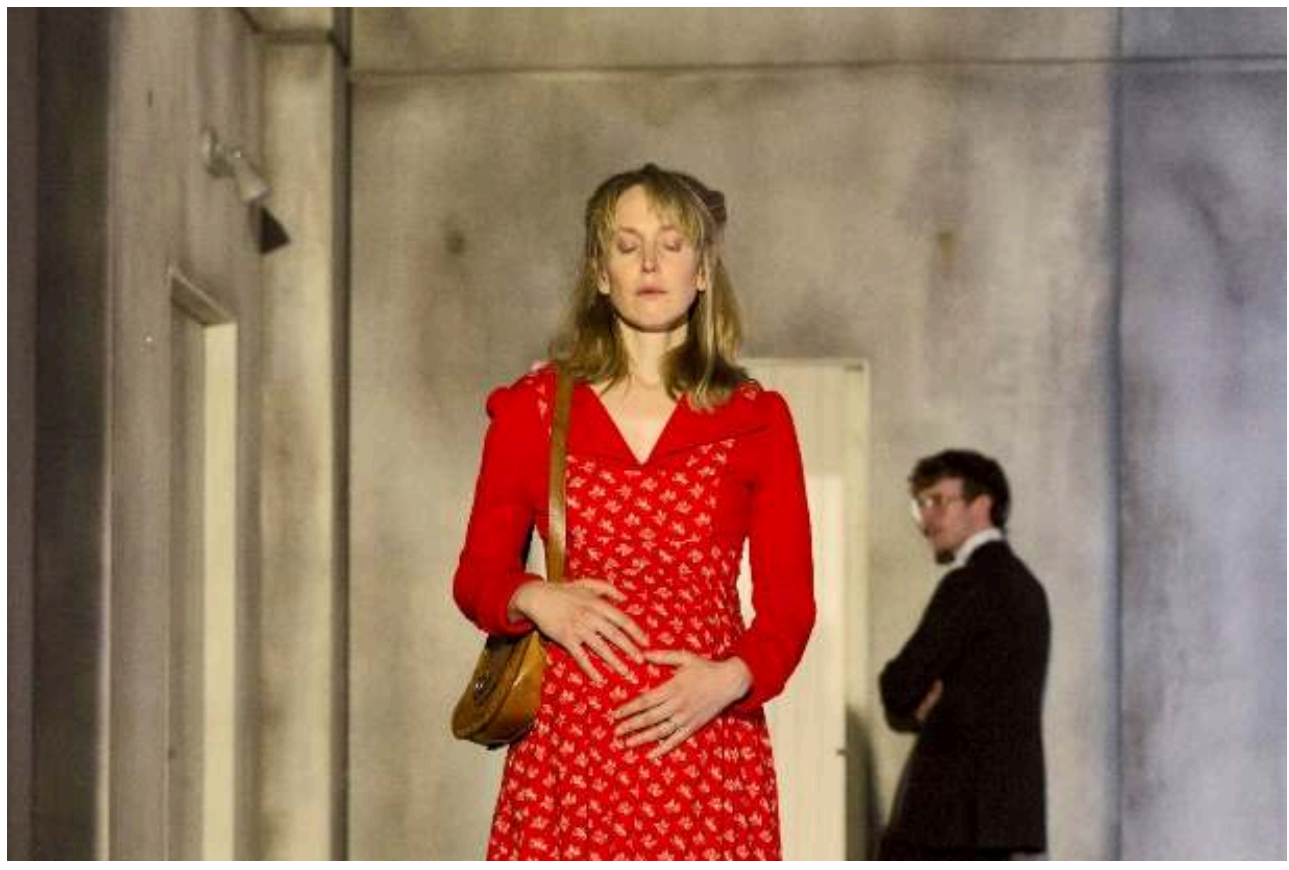

Hattie Morahan (Carol) and Peter Hobday (Dave)

Credits : Stephen Cummiskey

\section{Figure 7}

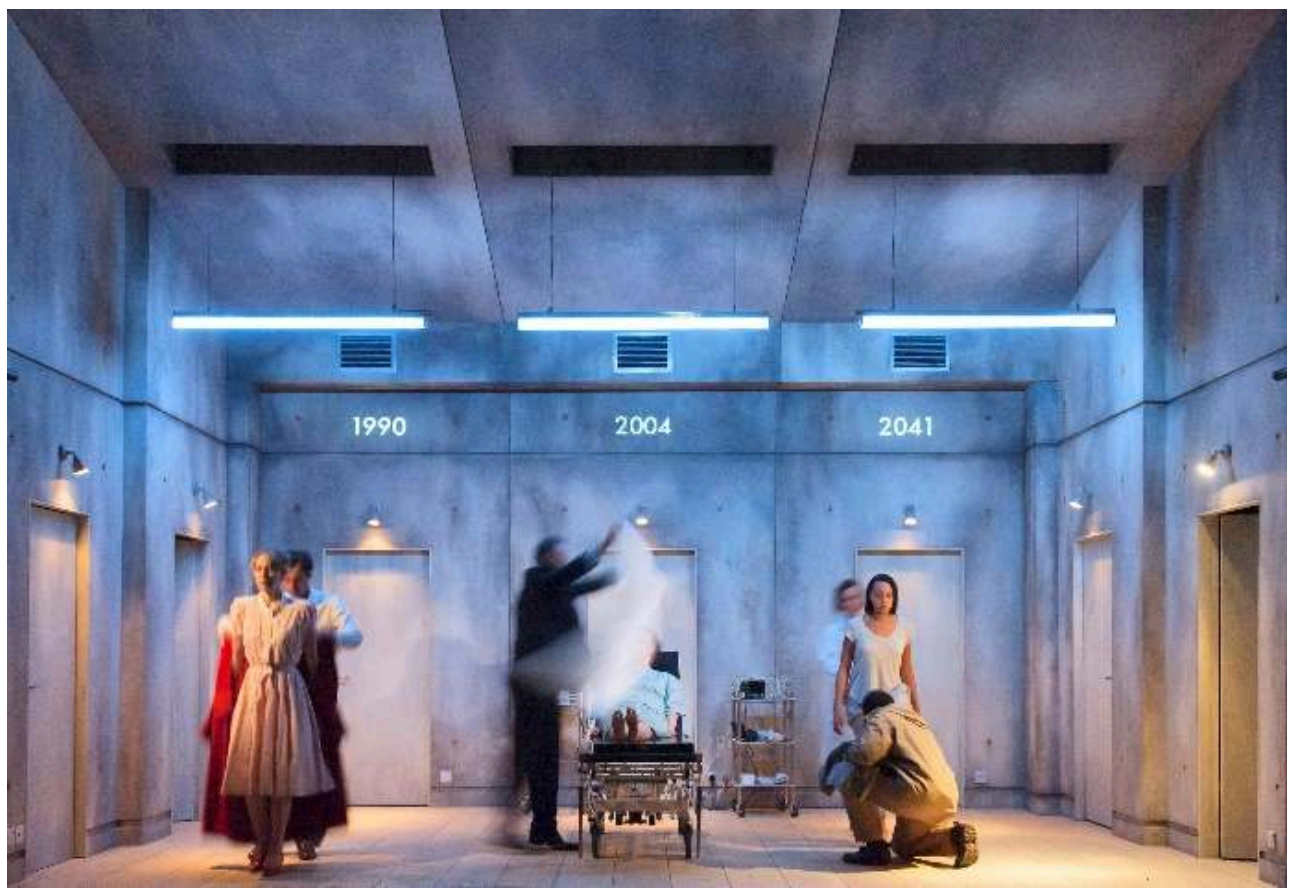

Hattie Morahan (Carol), Kate O'Flynn (Anna), and Adelle Leonce (Bonnie) Credits : Stephen Cummiskey 


\section{Review} Summer of Love. Playing in repertory during the early months of the summer, the Globe featured two takes on love with a contemporary version of Romeo and Juliet and Rice's own re-invention of Twelfth Night, her swan song on the Globe stage as its Artistic Director. When it comes to Shakespeare's comedies Twelfth Night has become a regular staple on London stages, seemingly popping up in various incarnations every two or three years. Even though I do not live in London, it always seems that during my trips to the city I always encounter "the"defining Twelfth Night production. In 2008 London was abuzz over the West End sell-out run for Michael Grandages's star heavy production, which included Derek Jacobi (Malvolio), Indira Varma (Olivia), and Victoria Hamilton (Viola).And yet, the next year the Royal Shakespeare Company followed with its music heavy production, including a Feste that serenaded the audience during intermission, that found its way to the West End, with Richard Wilson as the put upon Malvolio. A few years later in 2012 Tim Carroll's all male version sold out the Globe, the West End, and Broadway, featuring Mark Rylance's heartfelt turn as Olivia and Stephen Fry's pompous Malvolio. 2017 found two productions of Twelfth Night playing within months of each other. The National Theatre, focusing on the festive winter season inherent in the title, featured it on the Olivier Stage to overlap with the holidays, while a few months later Emma Rice's production premiered in the late spring.

Over my forty plus years of attending the theatre, I have seen over twenty productions of Twelfth Night, and I still excitedly look forward to two scenes: the evening revels between Feste, Toby, Andrew, and Maria, which the peevish Malvolio interrupts, leading Toby to be avenged on him; and the discovery by Malvolio of the fake letter from Olivia professing her love for him. The scenes rebound with humor, music and song, and opportunities for a director to put his/her own stamp on the play. In contrast to those two ebullient scenes, I always cringe at the Sir Topas scene, where Malvolio has been imprisoned by Toby. It is relentlessly dark and cruel and runs counter to the spirit of the play, plus it brings the energy and momentum of the story to a complete standstill. Rice's version, though, completely upended myusual expectations of the play by disrupting the usual narrative beats and providing a fresh theatrical presentation through her contemporary, hellzapoppin' production. Her re-envisioning featured new lines and songs, the cutting of a great deal of Shakespearean text, and a playful, spirited cast that not only brought the production to life in an entirely new manner for those familiar with the play, but also introduced Shakespeare in a fresh, relatable way for a new generation. This latter point was clearly seen on the faces of the tweens who sat in front of me, relishing the electric production and peppering their parents with questions about the characters, the plot, and Shakespeare.

The first sign that this production would not be an ordinary Shakespearean production occurred during the play's opening sequence, which featured music from an electric guitar led band, and opened on the Love Boat with dancing, white-bedecked passengers and crew members all being led by a sequined, wig wearing Feste in singing "We Are Family" until the boat wrecked, throwing everyone overboard. The first Shakespearean line of the play was finally uttered almost ten minutes into the performance. In staging such a lengthy pre-text sequence it would only make sense that Rice would make some cuts and changes to ensure that she did not end up with a three-hour long Twelfth Night. 
Many of the cuts that she instituted occurred in the three scenes I mentioned above. During the carousing scene in the play's second act, much is made by Shakespeare of the musical nature of their revelry, including the presence of Feste who leads the inebriated night owls in a number of different songs. Rice, who limits the role of Feste greatly, instead used the scene to highlight the romantic relationship between Toby and Maria. Unlike some productions where Toby comes to love Maria over the course of the play, here they were already a couple. And it is worth noting that for the first-time in all the productions I have seen Maria is presented as being as equally prominent as Olivia and Viola to the story, creating a triumvirate of strong women.

Another example of Rice's editing of Feste's role occurred in the Sir Topas scene, which was abbreviated dramatically, as again Rice used the scene for narrative purposes, in this case showing Malvolio's distress and his need for a pen and paper to write to Olivia, which is then read at the end of the play. Rather than the usual dark setting and ubiquitous staging of Malvolio emerging out of the stage floor, surrounded by bars, the stage stays bright and Malvolio instead sits on a bunk bed while talking with Sir Topas.The dark tone was removed, the scene was simplified, and the exuberance and energy of the production was not affected. Her decision to pare this problematic scene was a smart theatrical choice.

Usually the highlight of a Twelfth Night production is Malvolio's discovery of Maria's falsely penned note of Olivia's fondness for her cross-gartered servant. Directors milk the scene for all the potential comedic possibilities of Malvolio's engagement with the contents of the letter, the inventive ways to have Toby, Andrew, and Fabian hide, and the resulting angered reactions of Toby and the empty-headed musings of Andrew to Malvolio's comments. Rice, though, disrupted the usual expectations for this scene, cutting great swaths from Malvolio's speech about the letter (for example, the random inclusion of letters that Malvolio muses over was replaced by a big " $M$ " on the outside of the note). The scene became streamlined and the comedy truncated. Because of this change, it no longer was a show stopper and the final scene before intermission. Instead, intermission came after the next scene which takes place between Olivia and Viola. And when one considers Rice's theme for the summer Globe series, her choice made sense. After all, her focus was love. To end the first half of the play on the mean prank played on Malvolio and his own desire for vengeance on olivia's drunk kinsman devalued the nature of herthematic intentionality. There is no love present in that scene. Instead, Rice ended the first half of the play with the talk of love between Olivia and Viola, and even though they will not end up together at the play's end, both will be coupled with their own partners in a rousing final dance and song, capping off an innovative and refreshing take on one of Shakespeare's most produced comedies.

Emma Rice's tenure at the Globe was brief as she rankled purists with her vision of the playing space and Shakespeare's plays. Her production of Twelfth Night was an example of her vision of what Shakespeare can be and should be-a rousing, invigorating, reimagined production that engages audiences and makes the Bard fresh to a new and upcoming theatrical audience. While she will be moving on from the Globe, there is no doubt that her directing and leadership will be appreciated elsewhere and more innovative Emma Rice productions will be appearing in London soon.

While Emma Rice's concept relied on kinetic energy, movement and music, Katie Mitchell's direction of Alice Birch's Anatomy of a Suicide was on the opposite spectrum in terms of tone and subject matter. The play depicts the stories of three generations of 
women, Carol, mother to Anna, who is mother to Bonnie, and their struggles with depression and suicidal intentions. Birch's play continues the long line of plays by women that theatrically depict the generational recycling that exists between mothers and daughters. Whereas in many plays the mother and daughter interact and battle with one another, Birch disrupts this usual narrative pattern by her the mother and grown-up daughter interact. Instead, Birch opts to stage each character at the same point in their lives, when they are in their 20s and 30s. In order to do so, Birch presents three different time periods at once, allowing us to see the parallels and repetitions between their lives. Not only are there visual overlaps between the three time periods, but the characters also occasionally share dialogue, reinforcing the generational connection between them.

While the three women are linked through language, the delicacy of each of their mental states, and a family home that all three reside in, their individual existences have their differences. Carol, weighed down by motherhood and the limited expectations for women in the 1970s, is surrounded by and exudes silence. She is often alone and pensive. (Hattie Morahan powerfully conveys Carol's anguish through the crippling silence of just smoking a cigarette alone). When forced to engage in conversation with others, she is stilted and uncomfortable. In contrast her daughter Anna, who we first meet in a hospital after partying too much the night before, is a font of energy and constantly on the move, needing to find distractions from her dark thoughts. Hoping to find a bit more stability in her life, she moves back to her childhood home, where she lives with her husband and ends up giving birth to Bonnie. However, unlike her mother, who fights to suppress her suicidal feelings as long as she can for the sake of her daughter, Anna kills herself in the bathroom, while her infant daughter sleeps in the next room. (Unlike Carol's death, which is not staged, Anna electrocutes herself in the bath, drawing a strong response of shock from the audience the night I saw it.) Set in the future, Bonnie is a medical professional, trying to find respect at work and deal with a lover who will not leave her alone. While quiet, like her grandmother, the psychological struggle with depression and suicidal tendencies does not appear as severe for her. After the death of her father, she moves back into her childhood home, where she confronts the demons of her mother and grandmother's suicides. To stop, the tragedies from continuing further she opts to sterilize herself, halting the suffering with her generation.

The set has a deliberate institutional feel, contributing to the feeling of claustrophobia, oppression, and inescapability from the depression that plague all three women. However, once Carol and Anna have died, the stage is left to Bonnie, who has decided to reject the vicious cycle of her family, first, through her sterilization and, second, through the selling of the family home, to escape the memories of pain felt by her mother and grandmother. In the final scene the back wall rises to reveal a stark visual contrast to the rest of the play's aesthetic. Bonnie now stands in a vast downstairs room of her family home, brightly lit by sunlight streaming through a window (a glaring comparison to the dimmed lighting for the other scenes). Coming down the staircase are a happy, little girl and her smiling mother (the new buyer, perhaps ?), admiring and relishing the space. Birch and Mitchell's final vision here is open to multiple questions. Has Bonnie now successfully broken the curse of the depression suffered by her mother and grandmother? However, is escaping such a debilitating disease so easily accomplished ?Does the presence of the mother and daughter in the last scene suggest the banishment of depression and suicide from the house-after all 
the room is filled with light banishing the darkness that had affected the three previous generations of women there? Or is the presence of a mother and daughter a sign that the cycle will continue with a new family? If the latter, is the play suggesting that there is no escape from such debilitating thoughts and action for women? Part of what drives the uncertainty of these questions and the ending is that Birch never really explains why Carol and Anna experience the deep depression that they do and their desire to end their lives.While both Hattie Morahan and Kate O'Flynn enrich their sparse dialogue through their embodying of the physical and emotional suffering of their characters, the motivation is never adequately provided by Birch.

31 A comment on the playing space must be made. Having been a Royal Court theatre goer for almost thirty years, this might be the first production I have seen there where the stage proved to be too small for the production. Admittedly, Mitchell and Birch's intent was to create an intimate setting, but the boxing in of the stage to one tightly controlled playing space (except for the final reveal) was problematic visually, as each character's story was given a cramped amount of stage space. No doubt, one can argue that the cramped nature of the staging is effective in creating the atmospheric nature of the play (the idea that each woman is limited, boxed in by her own mental, familial, and societal struggles). However, from my perspective in an aisle seat in the back of the stalls, the visuals felt muddled and restricted.

Finally, it is worth noting that while it might have been the summer of love at the Globe in June and July of 2017, it is clear that this past summer was also the Summer of the Female Director, as these two works showed off the theatrical heft of Katie Mitchell and Emma Rice. Testifying to the power of their work, both productions played to sold out houses at two of London's premiere theatres, the Globe and the Royal Court. In addition, Yael Farber's rewriting of Salome, which she also directed, was on the Olivier stage throughout the summer. (Farber would go on to direct Knives in Hens at the Almeida later that summer.)The presence of these women shaping works and giving a new glimpse of classic stories testifies to the growing role of women in the British theatre.

\section{ABSTRACTS}

Theatre reviews, June/July 2017

Show : Twelfth Night by William Shakespeare-Globe Theatre (London), May 18th, 2017- August 5th, 2017 ; Anatomy of a Suicide by Alice Birch-Royal Court Theatre Jerwood Theatre Downstairs (London), June 3rd, 2017-July 8th, 2017.

Critique théâtrale, Juin/Juillet 2017

Spectacles : Twelfth Night de William Shakespeare-Globe Theatre (London), 18 mai, 2017- 5 août, 2017 ; Anatomy of a Suicide by Alice Birch-Royal Court Theatre Jerwood Theatre Downstairs (London), 3 juin, 2017- 8 juillet 2017. 
INDEX

Subjects: Theater

Mots-clés: metteuses en scène, comédiennes, suicide, adaptations textuelles, moderniser Shakespeare, espace de jeu

Keywords: female directors, female leads, suicide, textual changes, contemporizing Shakespeare, theatrical space

\section{AUTHOR}

WILLIAM C. BOLES

Professor

Rollins College, Florida (USA) 